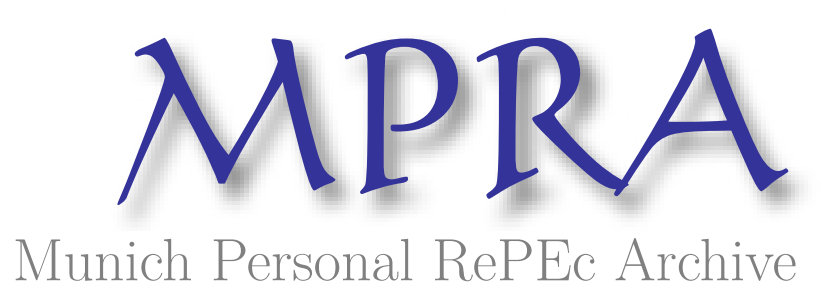

\title{
Critical review of the tools of Ijtihad used in Islamic finance
}

\author{
Abozaid, Abdulazeem
}

June 2016

Online at https://mpra.ub.uni-muenchen.de/92538/

MPRA Paper No. 92538, posted 23 Mar 2019 03:49 UTC 


\title{
Critical Review of the Tools of Ijtihad Used in Islamic Finance
}

\section{Abdulazeem Abozaid}

Associate Professor - Qatar Foundation

\begin{abstract}
Fiqh, indicating Islamic law and the means to produce it, covers all aspects of human dealings, including Islamic financial law and its Shariah nominated contracts, which represent the bases for all Islamic banking and finance transactions. These contracts are either readily found in the classic books of Islamic law or modified versions adopted to suit the modern transactions of Islamic finance. In some cases they are a combination of more than one contract designed to serve a particular financing purpose, like the contract of Ijarah Muntahia Bittamlik where the transaction starts with lease and ends with sale. This paper comes to discuss the most important ljtihad instruments that can be used by the Faqih to evaluate and endorse products in Islamic finance. It then elaborates on the instruments that are in use in the modern Islamic finance and which reflect a departure from Shariah rules and tools for ljtihad. The objective of this paper is to shed light on the cotemporary ljtihad in Fiqh of Finance in light of the guidelines provided by the Shariah in an attempt to draw the outlines of what constitutes a proper use of proper ljtihad instruments in Islamic finance.
\end{abstract}

Keywords: Ijtihad, Islamic Finance, Fiqh, Maslaha, Maqasid, Darurah, Shariah Policy. 


\section{Introduction:}

Islamic law is considered by Muslims to be the most flexible heavenly revealed law when compared with the other revealed laws in their original versions. Thanks to this flexibility, Islamic law can accommodate many market needs. Elements of flexibility of Islamic financial law include: Permissibility being the original rule in Shariah, Shariah rules being not all fixed or permanent for they include the Mutaghiyyrat (changeable) and prohibition in Shariah not being of the same degree. Equipped with a flexible basis for legislation, the faqih (Muslim jurist) is provided with general guidelines that help him reach sound and acceptable rulings. These guidelines teach the faqih to observe while judging or developing a transaction: the structure of the transaction, the essence of the transaction, the general as well as the particular Shariah objectives of the transaction and the implications of implementing the transaction. Shariah also teaches the faqih to prioritize these requirements when compromising some is necessary. Well-established Shariah concepts, however, like Shariah policy, public interest and necessity have been used in the modern fiqh (Islamic law), especially in Islamic finance, to reprioritize these requirements and sometimes to unjustifiably sacrifice some. Although these concepts are Shariah concepts and some are originally valid ljtihad (the process of deriving Shariah rules for the new incidents) instruments, applying them in the context of Islamic finance has raised major Shariah concerns. The following discussion outlines some of the valid ljtihad instruments for Islamic finance, and then it elaborates on the instruments effectively in use and their Shariah concerns.

\section{The Proper ljtihad instruments in Islamic Finance}

Shariah equips Shariah scholars conducting ljtihad with multiple ljtihad instruments that would help them structure and endorse products. The following are the most important ljtihad instruments at the disposal of the Mujtahid. ${ }^{1}$

\footnotetext{
${ }^{1}$ Mujtahid is the one who performs ljtihad, i.e. the process of deriving the Shariah rules from their sources.
} 


\section{Shariah texts and their interpretations}

Shariah texts refer to Quran and Sunnah. In the area of financial transactions Shariah texts provide general rules and rarely provide details. This is because the nature of the financial transactions changes as they may get more sophisticated over time. Therefore, it would not be convenient to provide details on the inherently changeable contracts, because these details would not be relevant then to the modern applications of these contracts. The general rules provided by the Shariah texts, however, are sufficient for Muslim jurists to deduce Shariah rules for the modern transactions. When attempting ljtihad, however, Muslim jurists may find that the same Shariah text pertaining to a financial transaction may be interpreted in multiple valid ways. In fact, this applies to most legal Shariah texts, and it explains the reasons why within the boundaries of Shariah existed different schools of Fiqh. Contemporary Shariah scholars do not need to restrict their fatwas (legal opinions) to one particular valid interpretation, or even to the interpretations made by the classic schools of Fiqh, as long as the interpretation they may opt for, or develop on their own, is basically valid; i.e. it is not in conflict with the established Shariah rules and principles, and the Arabic language admits that interpretation within the context of the text.

\section{Permissibility being the original ruling in Shariah}

In the absences of a clear and authoritative text, Mu'amalat (transactions) are deemed by Shariah to be halal (permissible). The prohibition, on the other hand, needs to be communicated to Muslims in definitive terms in order to be established over them. This, in fact, constitutes a vital tool for the Shariah scholars to endorse new Islamic banking and finance products and transactions. Any new structured products or transaction will be deemed as permissible as long as it is free from the prohibited elements like interest, gharar (uncertainty) or Ghabn (fraud).

\section{Prohibition being of different categories}


Prohibition in the Shariah is not of the same category especially in the field of financial transactions, for there exist the so-called haram lithatihi (unlawful in itself) and haram lighairihi (unlawful in consideration of something else). The first prohibition is applicable to cases where the evil is embedded in the very act, like in Riba where charging interest is an evil in itself, or in gambling where it involves unjustified seizure of others' properties. The second prohibition relates to acts that are originally lawful but made unlawful owing to the presence of certain conditions, like sale contract when concluded during Jum'a (Friday) prayer. ${ }^{2}$ Although sale contract is originally halal (lawful) by virtue of some textual evidences, it is deemed haram (unlawful) if concluded during Jum'a prayer since engaging with sale, or any other transaction/activity, may lead to the evil of missing the Jum'a prayer. In other words, the haram lighairihi is unlawful in view of its results and implications. ${ }^{3}$ Being so, there is an avenue for acts under this category of prohibition not to be regarded unlawful if they can be construed as non leading to the perceived cautions. This means that if care is exercised for the act not to be conducive to the feared evil, then the act may be regarded as lawful. This in fact adds to the flexibility to Islamic law and functions as a relaxing instrument particularly within the framework of Islamic financial contracts.

However, it remains the responsibility of Shariah scholars to identity the unlawful acts that can fall under this category of prohibition. This is in order to look into the possibility of excluding them by laying the appropriate conditions that will liberate these acts from their evil-producing nature. In this regard, it can be said that the very prohibition of gharar (uncertainty) is declared by some esteemed old Shariah scholars not to be meant for itself, but in conjunction with its possible evil implications (tahreem tharai'i) like the dispute it

2 Kamali, "Principles of Islamic Jurisprudence" p.330

3 For more details on this matter see Abozaid, Abdulazeem. (2007). "Examining the Malaysian Shari'a Guidelines for Islamic REITs", a paper presented at the International Conference on Islamic Capital Market, which was organized by Muamalat Institute \& Islamic Research and Training Institute in Jakarta, August 27-29. 
may lead to between the parties to the contract. ${ }^{4}$ This means that gharar is prohibited only when evils are expected; if, however, no evil or harm to be expected, then the contracts involving gharar may be deemed as lawful. This stand may be supported by the existence of many exceptions Shariah made to gharar prohibition, like in validating gharar-bearing contracts like Salam and Istisna ${ }^{5}$, and also in tolerating the minor gharar in all sorts of contracts.

\section{Analogy (Qiyas)}

Analogy is very instrumental for ljtihad, it relates to the extension of a Shariah ruling of an old established case to a new case when the latter shares the same effective cause (illah) of the former. Since Shariah texts have stated the rulings of many financial transactions, the jurist (Faqih) may make use of these stated rulings by applying the same to the new transactions if they are found to be sharing the same illah. For example, the modern day financial derivatives, when used for hedging, have been basically found to be similar in essence to gambling and games of luck, therefore they have been ruled by contemporary scholar as unlawful since gambling itself is stated by Shariah texts as unlawful. Thus, qiyas is very vital and useful instrument, and it in fact ensures consistency between Shariah and reason. The challenge however is, to certain extend, in identifying the illah and to larger extend in assessing the similarity of the new case with the old case; a process that jurists have termed as takhqiq al-manat.

\section{Public interests (Maslaha Mursala)}

$4 \mathrm{Ibn}$ Tayimiyah and Ibn Al-Qaiyyem have adopted this approach. Further details and discussion can be found in Al-Dareer, Al-Gharar wa Atharauhu fil Uqud, a book published in Arabic by Dar al-Jeel, 2009, second edition.

${ }^{5}$ Other examples include Khayar al-Shart (option of stipulation), and the sale of pregnant animals. In the first case, the contract is uncertain to the contractor who grants this option to the other and in the second case a part of the price goes implicitly to the pregnancy thought its outcome is not certain. 
By definition, Maslaha Mursala refers to any interest that is deemed to be beneficial to the society and which has no textual evidence on its authority or otherwise. It is a juristic device whose authority has been established based on the fact that all Shariah rules are meant to realize public benefits. Muslim jurists have built on this fact the notion of Maslaha; deeming as permissible anything that realizes public interest, and as invalid or impermissible anything that brings about harm and evil. One of the basic conditions, however, for the operation of this juristic instrument is for the perceived Maslaha not to be in conflict with any Shariah text or established principles, because the human perception of Maslaha may err, and Shariah texts and principles must prevail over any human legal exercise. ${ }^{6}$

Among the major figh schools, Maliki School is known to be the leading proponent of maslaha as one of ljtihad instruments and sources of Shariah. On the other hand, other figh schools reject it as independent source of Shari ah though they practiced it, possibly under a different name ${ }^{7}$, without theoretically admitting its authority as an independent source of the Shariah. ${ }^{8}$

\section{Relationship between maslaha \& maqasid al-Shariah (Shariah objectives)}

Maslaha directly relates to Maqasid al-Shariah since the very realization of maslaha is the primary objective of the Shariah. Protection of religion, life, lineage, intellect and wealth are

\footnotetext{
${ }^{6}$ The formulation of a rule on the basis of 'al-masalih al-mursalah' must take into account the public interest and conform to the objectives of Shariah. The application of this tool must fulfill three main conditions. First, it only deals with transaction matters (muamalah) where reasoning through rational faculty is deemed to be plausible. Second, the interests should be in harmony with the spirit of Shariah. In other words it must not be in conflict with any of its main sources. Third, the interests should be of essential and necessary (darurah) and not of a luxury type. For more details, see "The Devotional Dimension in Interest-oriented Shari'a Rulings" Article in Arabic, Journal of Islam in Asia, Volume 3, No 1, July 2006; Sobhi R. Mahmassani, The Philosophy of Jurisprudence in Islam (Kuala Lumpur: Open Press, 2000). 87-89.

${ }^{7}$ Istihsan, for example, which is adopted by the Hanafi school, leads in some of its applications to the same end result of Maslaha; it endorses Shariah rules based on their inherent benefits.

${ }^{8}$ Abozaid \& Dasouki, "A Critical Appraisal of The Challenges of Realizing Maqasid Al-Shari'ah in Islamic Banking and Finance", P 7, IIUM Journal of Economics and Management, International Islamic University Malaysia, Vol. 15, No 2, 2009.
} 
the five essential values of Shariah, and all Shariah rules revert to these values. Rules of Ibadah (devotions), for example, relate to the protection of religion. Islamic rules of financial transactions, on the other hand, relate to the protection of wealth. Protection of all these essential values is the ultimate maslaha for human beings and thus, it is the primary Shariah objective.

\section{Blocking the means to evil}

Among the valid juristic devices that the Mujtahid needs to uphold while attempting ljtihad on a Shariah issue is Sad al-tharaiy', which means blocking the means to evil before it materializes. A particular transaction could be lawful in itself but in view of its goal or outcome it may lead to evil and thus, it should be ruled as unlawful. Leasing a real estate property, for example, to a company that will use it as a gambling casino is unlawful though the lease contract in essence is lawful; this is in view of the implication of this lease contract, which is in this context facilitating the evil of gambling. Another application is sale contract when executed in a way that renders it an interest-bearing loan. Selling an asset on credit basis then buying it instantly on the spot for a cash price and in collusion with the buyer is effectively a Riba contract, whereby the original seller has advanced cash money to the buyer then claimed more from the same, and the asset of sale has been used only as a tool to presumably legalize the exchange of cash (inah sale).

In fact, Sad al-tharaiy' is of a special importance in Islamic finance since it protects it from the invasion of products that have a valid structure but an unlawful essence. It, in other words, helps ensure the identity of Islamic finance being genuinely distinguished from that of the conventional finance.

Thus, Sad al-tharaiy' is a juristic device that excludes rather than endorses new products, but yet it is an extremely vital tool to ensure the quality of the products being genuinely Shariah complaint and not conducive to the evils of the conventional banking and finance products. 


\section{Invalid ljtihad Instruments \& Applications}

Despite the valid instruments the Shariah equips the Mujtahid with when determining the Shariah validity of contracts and transactions as detailed above, the contemporary ljtihad in Islamic finance has departed from the proper tools and methodology of ljtihad by adopting inapplicable instruments, twisting or misusing of applicable ones and overlooking important instruments as it is detailed in the following discussions.

\section{Use of inapplicable instruments}

\section{Shariah Policy (al-Siyasah al-Shar'iyyah)}

The term Shariah policy has recently entered the jargon of the fatwas related to Islamic banking and finance. Some products and transactions have in their list of fatwa justifications the term Shariah policy. So what is Shariah policy and is it a valid instrument for endorsing products and transactions on its basis?

\section{a. Meaning of Shariah Policy}

Shariah policy, or al-siyasah al-Shar'iyyah, in its broad sense refers to the area in Islamic Fiqh that explains rulings related to policies and approaches taken in managing and organizing national policies in accordance with the spirit of the Shariah. It covers a whole spectrum of issues in areas like economics, the judiciary, politics and international relations. ${ }^{9}$ It is the management of the public and general affairs of the Muslim state in accordance with the public interests and the interest of the Muslim state.

\footnotetext{
${ }^{9}$ Abozaid \& Dasouki, "A Critical Appraisal of The Challenges of Realizing Maqasid Al-Shari'ah in Islamic Banking and Finance", P 7, IIUM Journal of Economics and Management, International Islamic University Malaysia, Vol. 15, No 2, 2009.
} 
Shariah policy involves different principles including striking the balance between what it is dictated by the circumstances and the stated Shariah rules. In other words, it gives the Muslim governor the needed flexibility to occasionally set aside an established Shariah rule in favor of a new rule recognizable by the Shariah if the latter serves the public interest in a better way. It may involve the temporary suspension of some Shariah provisions that relate to Mubahat (permissible things). In other words, it relates to Maslaha in its macro applications, and in some of its application it relates to the estimation of the general darurah (necessity) that is capable of rendering the prohibited things permissible or the obligatory things not mandatory.

\section{b. Who is to determine the Shariah policy?}

Shariah policy can only be determined by the Muslim government and cannot be left to be determined by individuals including Shariah scholars. This is because it relates to the management of the people and the state general affairs, which is the responsibility of the Muslim government. Assuming the responsibilities of the Muslim government by independent individuals opens the door to some evils. Naturally, if they empowered to do so, they may produce conflicting policies and serve their own interests rather than the public interests.

\section{c. Mishandling of Shariah policy in Islamic finance}

Shariah scholars assuming the Muslim government's responsibilities in determining Shariah Policies in Islamic finance

In the absence of Shariah-committed Muslim governments and their roles in drawing up the necessary Shariah policies in Islamic finance to meet the challenges facing this industry, individual Shariah boards and scholars have taken up this responsibility of the Muslim government and engaged themselves in practicing the Shariah policy. However, the danger stems from the fact that realization of the people's interests and the maintenance of 
Shariah objectives, which are the core of Shariah policy, will have been then placed at risk. This is because Shariah policy is a quite sensitive principle. When Shariah scholars play Shariah policy, their presumed transparency may be potentially challenged and be influenced by the material gains they may derive from the rules they determine on the basis of their exercise of the Shariah policy. Obviously, Shariah scholars are not neutral or independent in this regard, but rather beneficiaries from the rules they may justify on Shariah policy basis. In other words, it is justifiably feared that this very sensitive legal tool called Shariah policy may be misused by the Shariah boards to tolerate unlawful transactions that would please their employers (Islamic banks) under the pretext and the claim that these transactions serve the public interest or the economies of the Muslim countries. Besides, competitions between banks and lack of coordination among Shariah boards will very likely result in having conflicting assessments of the Shariah policy, yielding thus conflicting rules, products and stands on what constitutes a public interest. Eventually, it is the Ummah as a whole that will suffer from this practice and the Shariah policy will lead to what is just the opposite end of what it has been designed for.

It is for these two reasons that the Islamic Shariah gives the power of determining Shariah policy to the Muslim government and not to individual bodies or entities. In fact, it is a tool in the hands of politicians, as the name indicates, and not in the hands of anyone else, and the absence of Shariah-observant Muslim government does not give the right to Shariah people to assume responsibilities which cannot be theirs.

Moreover, determining an issue on the basis of Shariah policy is not simple; it is a process that involves observing different considerations such as the degree of urgency, measuring the harms against the benefits expected and the implications on all levels. It may also involve setting a timeframe that needs to be observed and possibly amended in light of the results, implications and the changing circumstances. Therefore, it is not a simple process but rather a one that requires an institution at the top government level. For this reason determining a Shariah policy is a joint governmental work. The Muslim ruler should set 
Shariah policies after consultation with the Shura ${ }^{10}$ council which houses trustful and independent consultants of different specialties and backgrounds.

Another important element that relates to the operation of Shariah policy is the enforcement of the policy, for the absence of the enforcement power may lead to opposite results. In the context of Islamic banking and finance, if not all of the financial institutions abide by the rules determined on Shariah policy basis, disorder and chaos will prevail, and these institutions will fail to play their perceived economic role in the society. Thus, even when the Shariah policy is played right by individuals, lack of enforcement will hinders its success and may turn it into a sheer evil.

However, none of the above is observed when Shariah policy is determined by individual Shariah scholars or Shariah boards, and apart from those conditions of the operation of Shariah policy, lesson of experience have taught us that transparency is not something that can be taken for granted in any person, and Shariah scholars being humans and fallible are not exception. In fact, Shariah dictates that transparency and credibility must be sought in anyone who is to hold an office attending to public affairs and needs, but being a practical and realistic religion, Shariah does not stop at this point. It, in fact, places rules and restrictions on the conduct and the behavior of such a person. The Muslim judge for example must be among the most trustworthy persons to be eligible for his position, but his proved trustworthiness never gives him the right to take fees or accept gifts from the parties attending his court, for this may trigger his instinctively sinful human nature and thus influence his judgment and cause him to deviate from the path of justice.

\section{The Principle of Darurah (Necessity)}

It is a well established principle in Islamic law that Darurah, which means necessity, renders the prohibited things permissible. This principle is unanimously agreed upon by all schools of Islamic law, and it constitutes a Fiqh maxim that reads "Necessities permits the

\footnotetext{
${ }^{10}$ Shura means consultation.
} 
forbidden" (Al-Dharurat Tubih Al-Mahzurat). It means that the forbidden can be unsinfully committed when necessary. However, when jurists discussed and explained the applications of this figh maxim they mentioned what is known in Arabic as dawabit, which means conditions and guidelines, for the functionality of this maxim. These guidelines (dawabit) are of course stated in or derived from the Shariah texts. One of these guidelines relates to the very concept of darurah or what really constitutes a darurah. The jurists' approach to the concept of legal darurah can be summarized by saying that darurah is something which is indispensable for the preservation and protection of the five essential values: Religion, Life, Intellect, lineage and Wealth. ${ }^{11}$ This means that the concept of darurah would give the Mukallaf (the Muslim charged with Shariah rules) the legal excuse to commit the forbidden when it becomes indispensable for his survival, spiritually and physically. ${ }^{12}$

Therefore, in order for the principle of darurah to be operative the underlying act must be indispensable for the survival of human being, i.e. it must be a necessity. However, some Fiqh schools have placed at par with necessity what is termed in the Shariah as Hajah (need) but only when it is public. The term hajah refers to a human need that is not essential for the survival of human beings, but it is important for their well being. In other words, hajah is what a human can survive without which but only with hardship and difficulties. For example, having a car is not a necessity in Shariah terms, but it could be a public need in some places.

\section{Misapplication of Darurah}

Darurah has been loosely used in Islamic banking and finance to justify products that would not pass Shariah scrutiny test and would breach basic Shariah rules. The justifying argument

11 Al-Shatibi, Al-Muwafaqat, 2/10.

12 Majallat Al-Ahkam Al-'adliyyah, section 22; Ibn Nujaim, Zainulddin, Al-Ashbah Wal Naza'ir, 1/105-107; Al-Seyoti, Jalaulddin, $(911 \mathrm{H})$. Al-Ashbah Wal Naza'ir, p.84-92; Al-Kurdi, Ahmad. Al-Madkhil Al-Fiqhi, p.48. 
predicates on the submission that such products are indispensible for the survival and longterm sustainability of Islamic bank due to certain uncontrollable considerations. Very clearly, this argument presumes that the very concept of banking is a necessity in itself, while in the actual fact banking is not indispensable for the Mukallaf's survival from the Shariah perspective, nor is it a public need in Shariah terms. If such darurah hypothetically exists, then it would rather legitimize dealing with conventional banks directly.

Obviously, when Shariah prohibits something it always provides alternatives. For example when Shariah prohibits zina it permits marriage, when it prohibits wine and pork for consumption it permits all other sorts of food and drinks. Likewise, when Shariah prohibits certain contracts such as contracts based on riba (interest) and gharar (uncertainty), it alternatively permits many contracts like sale, lease, salam, istisna', mudarabah and musharakah. To economists, such contracts are even better alternatives to riba and gharar, and ultimately can help develop a prosperous and healthy economy, while an economy that is based on riba and gharar deepens the disparity between rich and poor, and leads to inequitable and unjust wealth allocation in a given society. Thus, there is no darurah that may allow Islamic banks to abandon these beneficial contracts in favour of harmful and destructive ones.

Moreover, tolerating a sinful activity on the basis of darurah never justifies the claim of its original permissibility. Islamic banks have tolerated certain products on the basis of darurah then offered the same to the public as Shariah compliant products. Obviously, this is a betrayal of Shariah rules and a betrayal of the clients' trust, not to mention the negative effects of such attitude on the image of Shariah if not Islam in general. Promoting as Shariah compliant something which is not raises questions marks on the rationality of the religion by Muslim and non-Muslims alike, which may cause aversion to Islam.

\section{Misuse of valid instruments}

\section{Misuse of Maslaha}


Maslaha as a fiqh instrument has been overemphasized by contemporary ljtihad in Islamic banking and finance. In some cases it has been treated as a priority over Shariah texts and Shariah established rules. Upon the existence of a conflict between a Shariah text or established rule and a Mujtahid's (faqih's) perception of Maslaha, the latter has been sometimes given a priority over the established Shariah text or rule. This work is a departure from the legal Maslaha, i.e. the Maslaha the carries a legislative power in Islamic law, for a variety of reasons:

First, the claim of a possible conflict between Shariah text and maslaha is an erroneous claim. If the Shariah text or rule is definitive, then it cannot be in conflict with a real maslaha, because all Shariah rules aim at realization of maslaha. Therefore, in this case it is the assessment of maslaha by the Mujtahid which will be deemed erroneous. In other words, the issue of a potential conflict existing between a definitive Shariah text and the maslaha is not conceivable if we are viewing maslaha from a Shariah perspective. However, if we are viewing maslaha from a human perspective then the conflict is plausible, but the determination of what is beneficial and what is harmful cannot be left to human reasoning alone $^{13}$. Human reasoning it that regard plays a role only within the framework guided by Shariah (Nyazee 2000). This is because, the inherent limitations of human beings posit a strong reason which requires Divine guidance to ascertain what is right and what is wrong. ${ }^{14}$

Second, even if such a conflict hypothetically exists, then it is the Shariah texts that must be given priority over maslaha. This is particularly true since maslaha derives its authority from the Shariah text and not vice versa. It is illogical to give priority to a branch over its core and source of authority. ${ }^{15}$

\footnotetext{
${ }^{13}$ His argument is supported by a number of Qur'ānic verses. One of which is Qur'ān 23:71. Refer to Al-'iz bin Abdelsalam, Qua'id Al-Ahkam fi Masalih Al-Anam, 2/161.

${ }^{14}$ Abozaid \& Dasouki, "A Critical Appraisal of The Challenges of Realizing Maqasid Al-Shari'ah in Islamic Banking and Finance", P 7, IIUM Journal of Economics and Management, International Islamic University Malaysia, Vol. 15, No 2, 2009.

${ }^{15}$ Al-Zuhaili Wahbah, Al-Waseet fi Usul al-Fiqh, p. 361.
} 
Third, the approach of giving priority to maslaha fails to distinguish between a definitive (qat $y$ ) and a speculative (zanniy) text. If the text is definitive with regards to its authenticity (thubut) and meaning (dilalah), then the ruling it produces is final and binding; i.e. there is no room for human's perception of maslaha to add any interpretation to the text. While if ${ }^{16}$ the text is speculative with regards to its authenticity or meaning, then there may be an avenue for the perceived maslaha to further interpret and give meaning to the text in a way that does not hinder its realization. This is acceptable as long as the perceived maslaha meets all of its conditions: being public not private, authentic not false, definitive not probable. ${ }^{17}$

To summarize, upon presuming an occurrence of a genuine conflict between the Shariah text and the maslaha, then priority must be given to the Shariah text and not the perceived maslaha, this is provided the Shariah text is definitive it terms of authenticity and meaning. If, however, there is a justifiable doubt over the authenticity or the meaning of the text, then there is an avenue for the perceived maslaha to reconcile with the text.

\section{Twisted interpretations of Shariah texts \& Fiqh statements}

Some Interpretations of Shariah texts that came in the form of fiqh statements made by some figh schools have been twisted to help legitimize certain problematic Islamic banking and finance products. For example, although sale of future debt to a third party is ruled as unlawful by all figh schools based on some Shariah texts, its validity has been falsely attributed to some figh schools (like the Shafi'i school), and a groundless distinction has been made between a debt resulting from a loan contract and a debt resulting from other financial contracts; allowing the later and forbidding the former. In fact, both the validity of

\footnotetext{
${ }^{16}$ See in Al-Ghazali, Al-Mustasfah, p176; Al-Bouti, Dhawabit Al-Maslah, p119.

${ }^{17}$ Al-Bouti, Dawabit Al-Maslah, p.119.
} 
sale of debt and this distinction have no ground whatsoever, and this position is based on twisted interpretation of Shariah texts and some fiqh statement. ${ }^{18}$

Another example is Inah sale, although all fiqh schools base the permissibility of the contract on its essence and objective, rather than its form and structure, which is the basis for the validity of the contract, cotemporary fatwas in Islamic finance have implied the opposite; considering a contract Shariah compliant only if its form and structure are sound from Shariah perspective. Not only do these fatwas contravene Shariah texts and principles by basing contracts permissibility on their form and structure rather than essence and objective, but some of them attribute also such erroneous stand to the Shafi'i Figh School when they claim that this school rules the permissibility ${ }^{19}$ of inah sale. ${ }^{20}$

\section{Overlooking important instruments}

\section{Relevant Shariah texts}

Some Shariah texts have been overlooked in fatwas on Islamic banking and finance products although they are closely related to the fatwas in questions. For example, Shariah texts very clearly state that combining between a sale contract and a loan contract in one "لو يجل سلف وبيع" 21 "It loan), and like sale contract in this regard is any commutative contracts as elaborated by the

\footnotetext{
${ }^{18}$ For details on this issue refer to Abozaid, Abdulazeem. "Examining the New Applications of Sale of Debt in the Islamic Financial Institutions", Journal of Islam in Asia, Volume 5, No 2, December 2008. It can be downloaded from www.abdulazeem-abozaid.com

${ }^{19}$ For details on these sales see Abozaid, Abdulazeem "Contemporary Inah is it a sale or usury" a book published in Arabic by Dar Al-Multaqa, Aleppo, Syria, 2004; Abozaid Abdulazeem. "Contemporary Islamic Financing Modes between Contracts Technicalities and Shari'ah Objectives", Eighth Harvard University Forum on Islamic Finance, Harvard Law School - Austin Hall, USA, April 19-20, (2008).

20 Abozaid, Abdulazeem. "Examining Bay' al-'inah and its New Applications in the Islamic Financial Institutions", Journal of Al-Tamaddun, Volume 4, December 2008.

http://umrefjournal.um.edu.my/public/article-view.php?id=2318

${ }^{21}$ This Hadith is reported in many Sunnah authoritative books including: Sunan AbiDaud, (3504) and Sunan AlTermithi, (1234).
} 
jurists. ${ }^{22}$ This is because the sale or the commutative contract in general could be used to cater to interest in the loan contract. For example, interest can be catered to in sale contract by demanding a price that is higher or lower than the market value, like in the lender colluding with the borrower to give him an interest-free loan but conditional on the latter buying from the former something at higher than the market value, or selling him something at lower than the market value.

However, this Shariah text has been totally overlooked in a variety of products, like in a product named "Islamic Pawn Broking". Herein the bank provides a so-called interest-free loan but conditional on the borrower providing valuables that will be safeguarded by the bank against fees, so that the bank can profit from the loan indirectly through the fees charged on the safekeeping of the valuables. Another product is the service-based Islamic Credit Cards, the issuing bank provides the card credit on interest-free loan basis; however, it charges the card holder for the embedded services as well as the extra services coupled with the card, like the free stuff the card holder may be entitled to when subscribing to the card. This practice is basically valid, but provided the fees are against the services and not the loan. To ensure it is so, the market value of these services must not be lower than the fees charged on the card. However, in practice it is much lower, which means that the fees are meant to cater to the interest over the loan.

\section{Blocking the means to evil}

Although this instrument is vital and important for identifying the Shariah compliant products and for protecting contracts from being misused and manipulated as elaborated earlier, it has not received the due attention by Shariah scholars giving fatwas to Islamic banks. This is evidenced by the existence of products criticized for being genuinely no different from the conventional products, and by the misapplication of some Islamic finance products to the degree of distortion. Had this instrument been observed and applied, it would have removed these practices form the shelves of Islamic banks and filtered

\footnotetext{
${ }^{22}$ Al-Dasuqi. Hashiyah, 3/76.
} 
financing deals so that no financing would be given when resulting in unfavorable implications

\section{Conclusion}

From the past discussions it can be concluded that Shariah has equipped Muslim jurists and Scholars with useful and practical figh instruments that if used properly will yield sound transactions and products. However, some of these instruments were misused, others were overlooked and some inappropriate instruments were also introduced.

These practices have been responsible for the invasion of some controversial products into Islamic finance and to the misapplication of some other products. This phenomenon has been in fact the natural result of the disorder and the lack of or weak Shariah governance in Islamic banks. Despite the great importance of Ijtihad and fatwa in the field of Islamic finance and their serious implications, this area has not received the due attention. In fact, the situations call for the following urgent reforming steps:

- Ijtihad in Islamic finance must be exercised by ljtihad institution and not be individuals at least on the products level, whereby only an independent centralized Shariah committee shall have the sole authority to endorse or reject products.

- The independent central Shariah committee must include besides highly qualified Shariah scholars economists, lawyers and financial experts, and it must have a binding authority over the individual Shariah boards.

- In the absence of the Shariah-committed Muslim government, a body comprising highly qualified intellectuals of different relevant specialties, similar to Shura council, can be formed to handle matters related to Shariah policy, and it can collaborate with the central Shariah committee to determine the Shariah policy related to Islamic finance.

- All fatwas issued by individual Shariah boards or scholars must be subjected to scrutiny by the centralized Shariah committee. Procedurally, the centralized Shariah committee must have the authority to conduct unannounced Shariah auditing visits. 
- Shariah scholars setting on Shariah boards must be accredited by a centralized qualified institution based on certain criteria, excluding the Shariah specialists who do not qualify for ljtihad or fatwas.

Indeed, segregation between the ljtihad institution and the political system has led to chaotic approaches to ljtihad and fatwas by individual Shariah scholars. This disorder did not carry much of evil before, but with the advance of Islamic banks it produced serious damages. The same disorder and confusion, however, will inevitably take place even in other fields of the Muslims' affairs when they get the chance to be applied on institutional level, because the roots of the problem are the same; mainly the rupture between the political system and the ljtihad institution. 


\section{References}

- Abdulsalam, A.-I. (1999). Qawa`id Al-Ahkam fi Masalih Al-Anam. Beirut: Dar al-Kutub al'Ilmiyyah.

- Abozaid \& Dasouki, (2009). "A Critical Appraisal of The Challenges of Realizing Maqasid AlShari'ah in Islamic Banking and Finance", P 7, IIUM Journal of Economics and Management, International Islamic University Malaysia, Vol. 15, No 2, 2009.

- Abozaid Abdulazeem, (2006). The Devotional Dimension in Interest-oriented Shari'ah Rulings, Article in Arabic, Journal of Islam in Asia, Volume 3, No 1, July 2006.

- Abozaid Abdulazeem, (2008). Contemporary Islamic Financing Modes between Contracts Technicalities and Shari'ah Objectives. Eighth Harvard University Forum on Islamic Finance, Harvard Law School - Austin Hall, USA, April 19-20, 2008.

- Abozaid, A. (2004). Contemporary Inah: Is it a Sale of Usury? Aleppo: Dar al-Mutlaqah.

- Abozaid, Abdulazeem, (2008). "Examining Bay' al-'inah and its New Applications in the Islamic Financial Institutions", Journal of Al-Tamaddun, Volume 4, December 2008.

- Abozaid, Abdulazeem, (2008). "Examining Bay' al-'inah and its New Applications in the Islamic Financial Institutions", Journal of Al-Tamaddun, Volume 4, December 2008.

- Abozaid, Abdulazeem. (2007). "Examining the Malaysian Shari'a Guidelines for Islamic REITs", a paper presented at the International Conference on Islamic Capital Market, which was organized by Muamalat Institute \& Islamic Research and Training Institute in Jakarta, August 27-29. Unpublished article.

- AbuDaud (undated). Sunan AbiDaud. Beirut: Al-Maktabah Al-'asriyyah.

- Al-Bouti, M. S. R. (1982). Dhawabit Al-Maslahah fil Shari ah al-Islamiyah. $4^{\text {th }}$ Edition. Beirut: AlRisalah.

- Al-Dareer, (2009). Al-Gharar wa Atharauhu fil Uqud. Second edition. Beirut: by Dar al-Jeel.

- Al-Dasuqi, (undated). Hashiyah, Dar Ihia'a al-Kutub al-Arabiyyah, Beirut.

- Al-Ghazali. (1413). Al-Mustashfah. Beirut: Dar al-Kutub al-`llmiyyah.

- Al-Kurdi, A. (1986). Al-Madkhil Al-Fiqhi. Damascus: Damascus University Publication.

- Al-Shatibi. (undated). Al-Muwafaqaat. Beirut: Dar al-Fikr.

- Al-Tirmidhi (undated). Sunan al-Termithi. Cario: Dar al-Hadith.

- Al-Zuhaili, W. (1993). Al-Waseet fi Usul al-Figh. Damscus: Damascus University Publishing House.

- Ibn Juzai. (undated). Al-Qawanin Al-Fiqhiyyah. Beirut: Dar al-Kutub al-Ilmiyyah.

- Ibn Nujaim. (undated). Al-Ashbah Wal Nazooir (1st ed.). Beirut: Dar al-Kutub al-Ilmiyyah.

- Majallat Al-Ahkam Al-`Adliyyah.

- Mahmassani Sohail, (2000). The Philosophy of Jurisprudence in Islam. Kuala Lumpur: Open Press. 